\title{
Teaching Values Through The Moral Dilemma Approach in Social Studies Course
}

\author{
Ali ALTIKULAÇ*
}

\author{
Salih USLU**
}

Received: 24 July 2013

Accepted: 08 January 2014

\begin{abstract}
The aim of this study is to demonstrate experimentally how to be gained of values which are anticipated to teach in Social Studies curriculum, through the approach of moral dilemma and to reveal the impact of this approach on students' moral thinking processes. In this study, three values "responsibility, helpfulness and sensitivity to the natural environment" were selected that were targeted to teach in six grade social studies course. As a tool of data collection in research, moral dilemma scenarios which were prepared by the researchers, was used. Themes were formed in accordance with Kohlberg's Moral Development Theory while content analysis method that was chosen for analysis of obtained data, was performing. In conclusion, it was observed that moral assessments of participants were in conventional level mostly. Findings showed that moral dilemmas used in the application make students to think about reasons for their decisions and developed their moral reasoning ability.
\end{abstract}

Keywords: value education, social studies course, moral dilemma

\section{Extended Abstract}

Purpose and Significance: The values which are located in consciousness of the individual are motives that direct the behaviors. One of the major problems in today's world that we live in is interpersonal and societal conflicts revealed by people who can't internalize values enough. Therefore values education is increasingly attracting the attention of education scientists. In the secondary school level, the tasks of gaining desired values to the children and preparing them to social life are belongs to social studies course as well as other courses, perhaps the more. Research has shown the importance of social studies course regarding to gain value to individuals. According to Kohlberg's approach of moral dilemma that can be used in value education, the role of teacher is to assist students in ethical issues, to facilitate students' comprehend and to create the necessary discussions for developing moral judgment.

Students, who are pushed into a moral dilemma, try to solve their own dilemmas and thus have the opportunity to reconsider their own value judgments. People, who are pushed into the dilemma, not only focus on the possible results of one's actions in the example event, but also enter into the relevant person's mental and emotional world. The person who has stayed in mental contradiction and moral imbalance and can't easily solve this conflict, think more deeply and go into action to consider possible new solutions so s/he can solve the conflict (Power, Higgins \& Kohlberg, 1989: 56). Therefore, the effect of moral dilemmas on value education was examined in this study.

\footnotetext{
* Corresponding Author: Dr., Çukurova University, Faculty of Education, Adana, Turkey, aaltikulac@yahoo.com

** Assist. Prof. Dr. , Niğde University, Faculty of Education, Niğde, Turkey, salihuslu@nigde.edu.tr
} 
Methods: This study is action research which has been done using the method of qualitative research. The sample of research constitutes 44 students who study at sixth grade in a state secondary school in Ankara province. Moral dilemma scenarios were prepared in accordance with selected values "responsibility, helpfulness and sensitivity to the natural environment" that were selected by researchers. The same questions were asked to the participants at the end of each scenario: "What would you do if you were that person's place? Explain the reason for your action morally?" The participants, who were pushed into moral dilemmas, were requested to write the reasons of their answers. The reasons for the decisions made by the students were subjected to content analysis. Three main levels that were put forward in Kohlberg's theory of moral development were used in classification of the resulting code into themes.

Results: Three values "responsibility, helpfulness and sensitivity to the natural environment" were selected for this study. These values are tried to teach for students in accordance with the approach of moral dilemma and it was examined what based on of the students' decisions in different situations. When student responses (reasons) are examined, it can be said that the approach of moral dilemma has a positive effect on the teaching of the selected values. Students have usually given answers at the "Conventional" level that is the second level of moral development of Kohlberg, in accordance with their levels of cognitive development who are located in. It is also important to pushing them to moral reasoning and to find opportunity of testing their values as much as which level of the answers given and the reasons put forward by the students.

Discussion and Conclusions: Situations encountered in social life are not easy as much as making a choice between good and evil. To overcome with complicated conditions requires more complex mental processes. Some difficulties are encountered on direct teaching of values that are expected to be gained to students in the educational process. Learning of students the value on cognitive dimension and to defense when they asked about the relevant value does not show that they internalize this value in their own lives. Leaving the students in cases of moral dilemma in classroom environment provides thinking moral judgments in-depth and how to use these values in daily life. Children who are left in dilemma remain between protection of their benefits or to comply with the general moral rule. Different responses of participant show that a wide range of psychological factors influence them when deciding on. Looking at the reasons in particular, it was observed that students think extensively on a given situation and examine their value judgments.

The purpose of education according to Çiftçi (2003) is to develop specific ways of thinking rather than gain. Development comes true if only child or young realize their specific mental schemas that are insufficient, stay in imbalance to explain the facts and consequently develop the transformation of moral focusing. In this study, it was tried to 
be created that imbalance situations in provided moral dilemma wherein said and it was aimed to provide students realize their own moral transformations. 


\title{
Sosyal Bilgiler Dersinde Değerlerin Ahlaki İkilem Yaklaşımı Yoluyla Öğretimi
}

\begin{abstract}
Ali ALTIKULAÇ*
Salih USLU**

Makale Gönderme Tarihi: 24 Temmuz 2013

Makale Kabul Tarihi: 08 Ocak 2014

ÖZET: Bu araştırmanın amacı, Sosyal Bilgiler öğretim programında verilmesi ön görülen değerlerin, Ahlaki ikilem yaklaşımıyla nasıl verilebileceğini deneysel olarak göstermek ve bu yaklaşımın öğrencilerin ahlaki düşünme süreçlerine etkisini ortaya koymaktır. Bu çalışma için, altıncı sınıf sosyal bilgiler dersinde öğretilmesi hedeflenen üç değer "sorumluluk, yardımseverlik ve doğal çevreye duyarlılık" seçilmiştir. Araştırmada veri toplama aracı olarak, araştırmacılar tarafından hazırlanan ahlaki ikilem senaryoları kullanılmıştır. Elde edilen verilerin analizi için seçilen yöntem olan içerik analizi yapılırken, temalar Kohlberg'in Ahlaki Gelişim Kuramı'na uygun biçimde oluşturulmuştur. Buna göre katılımcıların ahlaki değerlendirmelerinin daha çok geleneksel düzeyde olduğu görülmüştür. Bulgular, uygulamada kullanılan ahlaki ikilemlerin öğrencilerin verdikleri kararların gerekçelerini düşünmelerini sağladığı ve onların ahlaki muhakeme yeteneğini geliştirdiğini göstermiştir.
\end{abstract}

Anahtar sözcükler: değer eğitimi, sosyal bilgiler dersi, ahlaki ikilem

\section{Giriş}

"Bizi etkilemeseler bile başka insanların eylemlerine neden bu kadar fazla önem veriyoruz?" veya "Bir kişinin yaptığı bir eylemin yanlış olduğuna nasıl karar veriyoruz?" Bu sorular ahlak psikolojisinin temelini oluşturur ve psikologların bu sorulara verdiği cevaplar, zaman içinde değişim göstermiştir. Psikologlar ahlaki muhakemenin duygusal ve mantık dişı süreçlerin öncelikli birer sonucu olup olmadığ 1 konusunda fikir ayrılığ alanlarında elde edilen bulgular, bir cevap üzerinde birleşmektedir: Duygular ve akıl her ikisi birden bu süreçte etkilidir (Grene ve Haidt, 2002: 517). Ahlakın bütünü, bir kurallar sistemi içinde oluşur ve ahlakın özü yalnızca bu kuralları benimseyen bireylerde aranabilir. Kant'ın yansitıcı analizi, Durkheim'ın sosyolojisi ve Bovet'in bireysel psikolojisi, hepsi bu noktada birleşir. Bu doktrinler, zihnin bu kurallara nasıl riayet ettiğini açıklama noktasında farklılaşmaya başlar (Piaget, 1932). Eğitimi genç nesilleri sosyalleştirme süreci olarak gören Durkheim (1961), akılcı bir ahlak eğitiminin mümkün olduğunu düşünmektedir; O'na göre çocuğu ahlaki açıdan etkilemek diğerleri tarafından kabul edilmiş belirli erdemler içinde onları yetiştirmek değildir. Bundan ziyade insan yaşamına kolaylıkla adapte olmuş bu genel eğilimleri, uygun yöntemlerle geliştirmektir.

Ahlak eğitiminin amacı bireyin ahlaki bir kişilik geliştirmesinin sağlanması ve bireyde olgun davranışlar konusunda alışkanlık kazandırıp, üstün ahlak1 gerçekleştirmektir. Bir ahlaki davranış köklü bir ahlak kuralı haline gelinceye kadar, istikrarlı bir şekilde tekrarlanmalıdır, böylece karakter haline gelir (Aydın, 2008: 57). Okullarda verilecek ahlak eğitimi zorla okutulan ve geçme notuna bağlanan derslerle başarılamaz. Ahlak eğitimi ancak dolaylı yoldan yapılabilir; iyi seçilmiş kitaplar ve okuma parçaları eleştirel bir yaklaşımla ele alınabilir (Yörükoğlu, 2008: 229).

\footnotetext{
* Sorumlu Yazar: Dr., Çukurova University, Faculty of Education, Adana, Turkey, aaltikulac@yahoo.com

** Assist. Prof. Dr. , Niğde University, Faculty of Education, Niğde, Turkey, salihuslu@nigde.edu.tr
} 
Sosyal Bilgiler eğitimi toplumsal bağlamda bireyin gelişimiyle ilgilenir; bu bireysel gelişim, içinde oluştuğu toplumsal düzen için zarar verici olmadığı sürece desteklenir. Toplumsal gruplar tarafından tasarlanmış ve tarihsel süreç içinde ortaya çıkan bağlayıcı sosyal sınırlamalara sahip olsak da hala bu sınırlamalar için yapılması gereken "uygun" tanımlar vardır. Sınırlamaların varlığından ötürü ahlak eğitimi meselesi, uzun zamandır sosyal bilgiler eğitimcilerinin ilgisini çekmektedir. Genel manada ahlak eğitimi uygun sinırlamaları ortaya koyan ve toplumu bir arada tutan "sosyal yapıştırıcı" olarak işe sürülmektedir (Armstrong, 1980: 315). Bireyin kendisini, toplumun ise bireyi kontrol etmesini sağlayan unsurların başında değerler gelmektedir (Yazıc1, 2006). John Dewey'e göre değer, öncelikli olarak sayg1 duyulması, takdir edilmesi ve kıymeti bilinmesi gereken anlamına gelir. Bir şeye ulaşma ve onu muhafaza etme eylemi, ayrıca diğer şeylerle karşılaştırıldığında değerlerin miktarı ve doğası üzerine yapılan muhakeme eylemi anlamına da gelmektedir (Venkataiah, 2007). Değer Kavramı, bir sosyal grup veya toplumun kendi varlık, birlik, işleyiş ve devamını sağlamak ve sürdürmek için üyelerinin çoğunluğu tarafından doğru ve gerekli oldukları kabul edilen ortak düşünce, amaç, temel ahlaki ilke ya da inançlar olarak ifade edilmektedir. Değerlerin genel özellikleri: Toplum ya da bireyler tarafından benimsenen birleştirici olgulardır. Toplumun sosyal ihtiyaçlarını karşıladığına ve bireylerin iyiliği için olduğuna inanılan ölçütlerdir. Sadece bilinç değil, duygu ve heyecanları da ilgilendiren yargılardır. Değerler, bireyin bilincinde yer eden ve davranışı yönlendiren güdülerdir (Özgüven, 1999: 367).

Değer eğitimi, çocuklara hümanizm duygusu kazandırmak için onları telkin etmek, ayrıca diğer insanlar ve ülkenin refahını düşünmelerini sağlamaya çalışmaktır. Bunu başarmanın tek yolu çocuklara, değerlere karşı duyulan derin bir bağlılık duygusu aşılamaktır. Değerler eğitimi yoluyla örgün eğitim içinde giderek yok olan kişinin sosyal, ruhsal, ahlaki ve estetik yönü geliştirilmek istenmektedir. Değerler eğitimi, değerleri zorla kabul ettirme veya beyin yıkama işlemi değildir (Venkataiah, 2007). Değerler eğitiminin hedefi, bireylere kendi kişisel, sosyal, ahlaksal ve ruhsal değerlerini seçmeleri ve bunları derinleştirmeye yarayacak pratik yöntemleri fark etmeleri için ilham vermektir (Balc1, 2008: 25).

Değerler eğitiminde kullanılan birçok yöntem vardır; bu yöntemlerden birisi Ahlaki muhakeme yöntemidir. $\mathrm{Bu}$ yöntemde esas amaç öğrencilerin davranışlarına rehberlik edecek ahlaki ilkeler geliştirmelerine yardım etmektir. Öğrenci değerlendirme yaparken kullandığı dayanaklar bireyin ahlaki gelişimi hakkında bilgi verir. Burada öğrencinin çözümü değil çözüme ulaşma yolu önemlidir (Akbaş, 2008: 16). Ahlaki muhakeme yönteminde öğrencilere ikilemli durumların yer aldığı hikâyeler, örnek olaylar verilerek onların düşünerek, tartışarak ideal olan değere ulaşmaları sağlanır (Karatay, 2011). Ahlaki muhakeme yeteneği gelişmiş kişiler aynı zamanda eleştirel ve rasyonel müzakere yeteneğine sahip olurlar; kendi fikirlerine uymayan fikirlere hiç düşünmeden karşı çıkıp reddetmek yerine bunları dinleyebilir, eleştirerek değerlendirebilir, gerektiğinde ön düşüncelerini erteleyebilir, yenileyebilir veya değiştirebilirler (Çiftçi, 2003: 44). Ahlaki muhakeme her zaman zaaf ve erdem arasında 
veya başka bir deyişle siyah ve beyaz arasında olmaz. Çok daha sıklıkla çatışma erdem ve erdem arasındadır; dolayısıyla ikilem ifadesi bir soru olarak ortaya çıkar, "Ne yapmalıyım?” (Bull, 1969: 257). İkilem içinde bırakılan kişi, sadece örnek olaydaki kişinin olası eylemlerinin sonuçları üzerine odaklanmaz, ayrıca o kişinin zihinsel ve duygusal dünyasına da girmiştir. Zihinsel çelişki ve ahlaki dengesizlik içinde kalan kişi, bu çatışmayı kolayca çözemez, daha derin düşünür ve çatışmayı çözebilecek olası yeni çözümleri düşünmek için harekete geçirilir (Power, Higgins ve Kohlberg, 1989: 56). İkilem teoride çözümsüzdür ama uygulamada bir çözüm bulmak gereklidir. İkileme yönelik ilk çözüm teşebbüsü kaçınma şeklinde olur. Fakat verilen öncüller gerçek ise kaçınma imkânsız hale gelir. Eğer verilen durumlarda kaçınmanın bir yolu yoksa ve bu durumlar gerçek hayatın karmaşıklığını içeriyorsa, birey hangi seçeneği kabul edeceği konusunda bir kez daha düşünecektir (Harding, 2010: 45).

Ahlaki çatışmalarla ilgili en çok atıfta bulunulan, en eski örnekler Platon ve Sartre'ın ortaya koyduklarıdır. Platon'un ünlü eseri (Republica) "Cumhuriyet”te, Cephalus "adalet"i gerçeğin söylenmesi ve borcun geri ödenmesi olarak tanımlar. Sokrates bu açıklamayı bazı borçları geri ödemenin yanlış olabileceğini ileri sürerek hızla çürütür -örneğin ödünç aldığınız bir silahı aklı başında olmayan arkadaşınıza iade etmek gibi. Sokrates'in vurguladığı nokta bir borcu geri ödemenin ahlaki bir anlamı olmadığı yönünde değildir, bunun ötesinde $\mathrm{O}$, birinden aldığınız borcu geri ödemenin her zaman en azından tam olarak doğru olmayacağını göstermek istemiştir. Ne var ki burada iki ahlaki norm arasında bir çatışma söz konusudur: bir insanın borcunu geri ödemesi ve diğer insanların zarar görmekten korunması. Bu durumda Sokrates ahlaki norm olarak diğer insanları zarar görmekten korumayı öncelikli olarak görmektedir. Yaklaşık yirmi dört yüzyıl sonra Jean-Paul Sartre'ın açıkladığı ahlaki çatışmasının çözümü Platon'un çatışmasının çözümünden biraz daha zordur. Sartre, erkek kardeşini 1940 yılındaki bir saldırıda Almanların öldürdüğü bir öğrencisinden bahseder. Bu öğrenci kardeşinin intikamını olmak ve şeytani olarak gördüğü güçlerle savaşmak istemektedir. Ancak öğrencisinin annesi onunla birlikte yaşamaktadır ve $O$ annesinin hayattaki tek tesellisidir. Öğrenci birbiriyle çatışan yükümlülükleri olduğuna inanmaktadır. Sartre onun iki tür erdem arasında parçalandığını açıklar: bunlardan birincisi dar kapsamlı ama kesin etkiye sahip annesine olan kişisel bağlığı, diğeri ise çok daha geniş kapsamlı ama sınırlı etkiye sahip, haksız bir saldırganın yenilgiye uğratılmasına yardım etme teşebbüsüdür (McConnell, 2010).

Kohlberg, Piaget'nin zihin ve ahlaki gelişim alanında yaptığ incelemelerden ve ortaya koyduğu dönemleri dikkate alarak Ahlaki Gelişim Kuramını ortaya koymuştur. “1. Ceza - İtaat, 2. Çıkara Dayalı Alış veriş, 3. Kişilerarası Uyum, 4. Kanun ve Düzen, 5. Sosyal Anlaşma, 6. Evrensel Ahlaki İlkeler” olmak üzere altı aşama, üç seviyede gruplandırılmıştır: “1. Gelenek Öncesi”, “2. Geleneksel” ve “3. Gelenek Ötesi (İlkelere Dayalı)". Bu üç seviyeyi anlamanın bir yolu onları, kişi ve toplumun ahlaki kuralları ve beklentileri arasındaki ilişkilerinin farklı üç tipi olarak düşünmektir. Bu bakış açısından bakıldığında Kohlberg, her düzeyin kendine özgü bir sosyo-ahlaki bakış açısına sahip olduğunu varsaymaktadır. Düzey 1 (Gelenek Öncesi) kurallar ve toplumsal beklentilerin bireyin kendisi dışında var olduğu bakış açısıdır: Somut - Bireysel bakış açısı. Düzey 2 (Geleneksel) kendini diğerleri özellikle otorite tarafindan belirlenen kabul gören kural ve beklentileri benimseyen ve bu şekilde tanımlayan bakış açısıdır: Toplum - Üyesi bakış açısı. Düzey 3 (Gelenek Ötesi) kendini diğerlerinin kural ve beklentilerinden farklılaştıran ve kendi seçtiği prensipler bakımından ahlaki değerleri tanımlayan bakış açısıdır: Toplum - Öncelikli bakış açısı (Colby vd., 1987: 16). 
Kohlberg, çocukların ahlaki gelişimlerini incelemek için onlara kısa hikayeler sunmuş ve onlardan hikayedeki kişinin, bu durumda nasıl hareket etmesi gerektiğini sormuştur. Piaget, anlattığı hikâyelerde fiil ve düşünce ayrımı yapmazken, Kohlberg, hikâyelerde ahlaki ikilemlere (dilemmas) yer vermiş ve bunun çözümü için öneriler istenmiştir. Kohlberg tarafindan geliştirilen hikayelerde, kişinin sorunu nasıl çözdüğü kadar, çözümü gerçekleştirirken yürüttüğü ak1l yürütme süreci ve niçin böyle davranması gerektiğine ilişkin mantıksal dayanakları da önemlidir (Aydın, 2008: 51). Ahlaki ikilem içeren bu hikayeler, kötü davranışın muhtemel sonuçlarıyla ilgili belirsizlik içerir. Günlük hayatın gerçekliği içinde insanlar sadece kendi ahlaki düşüncelerine uygun ahlaki seçimlerinin sonuçlarına katlanmak zorunda kalmazlar, ayrıca bu sonuçlarla karşı karşıya kalmak onların daha sonraki ahlaki düşünme tarzlarını da büyük ölçüde etkileyecektir. Ahlaki kararların bir kişinin hayatının yönünü değiştirebileceği düşünüldüğünde, sözü geçen muhtemel sonuçlar hafife alınamaz (Bandura, 1991). Kohlberg ve takipçileri ahlaki ikilemler ve bu ikilemlerin çözümlemelerine ahlak eğitim programında önemli bir yer vermişlerdir. Kohlberg'i savunanlar da eleştirenler de ahlaki ikilemlerin doğasıyla ilgili çok az tartışma ortaya koymuşlardır (Rosen, 1980: 232).

Smetana (2006), çocukların ahlaki muhakeme becerisinin biçimlenmesinde ve farklılaşmasında cinsiyet, sosyo-ekonomik durum ve etnik köken gibi faktörlerin rol oynadığına dikkat çekmektedir. Diğer taraftan ahlaki muhakeme, karşılaş1labilecek tüm kritik durumlarda bir kişinin yaşam felsefesine ve hedeflerine, çevrenin etkisine, ahlaki olgunluğuna (Piaget tarafından vurgulanmıştır) ve ahlaki alışkanlık biçimlerine dayanır. Ahlaki uygulamanın mutlak olarak ahlak bilgisine dayanmadığı yönünde yaygın bir görüş vardır. İyi olanı biliyor olmak, iyi olanı yapacağımız anlamına gelmiyor. Çocuklara erdemli olmaları için ahlaki bilgiyi vermek başarı sağlamaya yetmez. Eğitim sürecinde ahlaki değerlerin açıklaması, çocuklar arasında ahlaki muhakeme ve uygulamaların yapılması, alışkanlık ve tutumların biçimlendirilmesi büyük önem arz etmektedir (Sharma, 2003).

Harding (2010), çocuklar ve yetişkinlerin ahlaki ikilemlerle ilgili düşünceleri üzerine yaptığı araştırmasının bazı sonuçları şöyledir: İkilemlerle ilgili alınan kararlar adalet ilkesine, dikkate veya bireysel çıkara dayanabilir; kararların, en azından gerekçelerine bakıldığında, çocukların yaşlarına, bilişsel yapılarının gelişimine ve özellikle merhamet gibi duygularını işe sürmedeki yeterliliklerine göre değiştiği görülmektedir; eğitim yoluyla karar-verme sürecinin değiştiği ve yine eğitim yoluyla ahlaki ikilemlerin çözülmesinin daha etkili hale geldiği görülmüştür.

Bir alternatif olarak varsayıma dayalı ahlaki tartışma yaklaşımına verilen önem, Kohlberg ve Fenton'un yaptığı sosyal bilgiler öğretmenlerinin varsayıma dayalı ikilem tartışmalarına rehberlik ettiği oldukça büyük ölçekli bir projeden sonra daha da belirgin hale gelmiştir. Sınıflarda yapılan ahlaki tartışmanın etkililiği üzerine yapılan bu araştırma, öğrencilerin ahlaki muhakeme yeteneğinin gelişimi üzerinde anlamlı bir farklılık göstermiştir (Power, Higgins ve Kohlberg, 1989). Bir başka çalışma ise, 1988 1990 yılları arasında Chicago'da uygulamaya konulan Okullarda Ahlaki Yaşam 
Projesi'dir. Proje, öğrencilerin ahlaki değer gelişimi üzerinde okulların ve öğretmenlerin doğrudan ve dolaylı etkisi üzerine odaklanmıştır. Bu etnografik araştırma: ahlaki değerlerin okul kültürünün bir parçası olmasını ve ahlaki düşüncelerin okul yaşamının tüm yönlerine yayılma yollarını vurgulamıştır. Öğretmenler tarafından yapılan tüm konuşmalar, davranışlar, tepkiler, kararlar ve hareketlerin ahlaki bir mesajı iletmesine özen gösterilmiştir ve araştırmada ahlaki öğrenmenin yer aldığı kompleks süreçleri vurgulayan tipik sınıf senaryolarından yüksek duyarlılıkta, ayrıntılı yorum ve analizler elde edilmiştir (Halstead ve Pike, 2006). Yapılan araştırmalardan hareketle bu çalışmada öğrenciler, seviyelerine uygun biçimde ahlaki yönden düşünmelerini sağlayacak örnek durumlar içine itilerek, onlara sahip oldukları değerleri sınama şansı verilmiştir.

\section{Yöntem}

$\mathrm{Bu}$ çalışma nitel araştırma yöntemi kullanılarak yapılan bir eylem araştırmadır. Bu çalışmada, Ahlaki İkilem yaklaşımının değer eğitimindeki etkisi incelenmiş; çeşitli ahlaki ikilem durumlarında bırakılan katılımcıların verecekleri kararlar ve gerekçeleri araştırılmıştır. Öğrenciler tarafından verilen kararların gerekçeleri içerik analizine tabi tutulmuştur. Bu çalışmada kullanılan eylem araştırması yöntemi, bizzat uygulamanın içinde olan uygulayıcının doğrudan kendisinin ya da bir araştırmacı ile birlikte gerçekleştirdiği ve uygulama sürecine ilişkin sorunların ortaya çıkarılması ya da hâlihazırda ortaya çıkmış bir sorunu anlama ve çözmeye yönelik sistematik veri toplamayı ve analiz etmeyi içeren bir araştırma yaklaşımıdır. Bu yaklaşım uygulayıcıya yeni bilgiler, beceriler ve deneyimler kazandırır ve kendi uygulamalarına karşı eleştirel bir bakış açısı geliştirmesine yardımcı olur. (Yıldırım ve Şimşek, 2006). Uygulanan yaklaşımın niteliği ve katılımcıların yorum ve açıklamaları incelediği için en uygun araştırma yönteminin nitel araştırma yöntemi olduğuna karar verilerek uygulanan ahlaki ikilem yaklaşımının katılımcılarda meydana getirdiği zihinsel süreçler ortaya konulmaya çalışılmıştır.

\section{Evren ve Örneklem}

Çalışma grubu belirlenirken nitel araştırmanın amaçlı örnekleme yöntemlerinden tipik durum ve kolay ulaşılabilir örnekleme yöntemleri tercih edilmiştir. Amaçlı örneklem üzerinde çalışlacak durum veya durumlarla ilgili derinlemesine ve zengin verilerin toplanmasına olanak sağlar (Yıldırım ve Şimşek, 2006). Ankara ili merkeze bağlı bir ilköğretim okulunda 6. sınıfta öğrenim görmekte olan 44 öğrenci, bu çalışmaya katılmıştır. Çalışma grubunu oluşturan öğrencilerin 24'ü k1z, 20'si erkektir. Araştırmanın uygulama ve veri toplama aşaması 2012-2013 eğitim öğretim yılı ikinci döneminde yapılmıştır.

\section{İşlem}

$\mathrm{Bu}$ çalışmada, araştırmacılar tarafından oluşturulmuş altı adet ahlaki ikilem senaryo kullanılmıştır. Ortaya konan ahlaki ikilem senaryoların uygunluğu konusunda iki alan uzmanı ve iki dil uzmanından görüş alınmıştır. Sosyal bilgiler programında doğrudan verilecek değerler arasında yer alan Yardımseverlik, Sorumluluk ve Doğal 
Çevreye Duyarlılık değerlerinin her biri için ikişer senaryo hazırlanmıştır. Araştırmada çalışma grubuna yapılan uygulama, aynı zamanda veri toplama aracı olarak kullanılmıştır. Her senaryonun sonunda katılımcılara aynı soru yöneltilmiştir: "Siz o kişinin yerinde olsaydınız ne yapardınız? Ahlaki yönden yaptığınız eylemin nedenini açıklayınız?" Katılımcılardan cevaplarını yazmaları istenmiştir.

\section{Verilerin Analizi}

Katılımcıların verdiği cevaplar için içerik analizi yapılmıştır. Ölçeğin ikinci bölümünden elde edilen Nitel verilerin analizinde ise içerik analizi kullanılmıştır. İçerik analizi, "sözel, yazılı ve diğer materyallerin içerdiği mesajı, anlam ve/veya dilbilgisi açısından nesnel ve sistematik olarak sınıflandırma, sayılara dönüştürme ve çıkarımda bulunma yoluyla sosyal gerçeği araştıran bilimsel bir yaklaşımdır." (Tavşancıl ve Aslan, 2001). Veriler; içerik analizine tabi tutulmuş ve nitel verilerin sayısallaştırılmasında kullanılan frekans tekniğiyle tablolar halinde sunulmuştur. Elde edilen kodların temalar halinde sınıflandırılmasında, Kohlberg'in ahlaki gelişim kuramında ortaya koyduğu üç temel düzey kullanılmıştır. Bunlar: I. Düzey “Gelenek Öncesi”, II. Düzey “Geleneksel” ve III. Düzey "Gelenek Sonrası”. Rakamların daha anlamlı bir şekilde yorumu için katılımcıların görüşlerinden doğrudan alıntılar yapılmıştır. Ahlaki ikilem durumunda bırakılan katılımcıların verdikleri kararlar için iyi veya kötü olarak sınıflandırılma yapılmamıştır. Zira katılımcıların içinde bırakıldıkları ikilem durumları genelde iki iyi arasında karara varma şeklindedir. Araştırmada ortaya konmaya çalışılan aldıkları kararlardan ziyade bu kararların alma nedenleri yani katılımcıların ahlaki muhakeme biçimleridir. Katılımcıların aldıkları kararların gerekçeleri düzeylere göre kategorize edilirken Kohlberg'in ahlaki gelişim kuramında her bir düzey için ortaya koyduğu zihinsel süreçler dikkate alınmıştır.

\section{Bulgular}

$\mathrm{Bu}$ bölümde, araştırmada kullanılan ahlaki ikilem senaryoları ile bu senaryoların sonunda sorulan soruya verilen cevaplar analiz edilerek yorumlanmıştır. Araştırmada kullanılan altı ahlaki ikilem senaryosu doğrultusunda elde edilen cevaplar, ayrı ayrı ele alınarak tablolar halinde sunulmuştur. Katılımcı öğrencilerin verdiği cevaplar(gerekçeler), Kohlberg'in ahlaki gelişim düzeylerine uygun biçimde analiz edilmiştir. Ayrıca öğrencilerin yapılan uygulamayla ilgili görüşleri, son kısımda sunulmuştur.

\footnotetext{
Ahlaki İkilem 1 (Yardımseverlik 1)

Mustafa, altıncı sınıfta okuyan oldukça çalışkan bir ortaokul öğrencisidir. Sosyal Bilgiler dersinde aldığ m müze tanıtımıyla ilgili ödevi titizlikle hazırlamış ve sınıfta sunmuştur. Öğretmeni Mustafa'ya sunduğu ödevi çok beğendiğini belirtmiştir. Ayrıca söz konusu müzeye birkaç gün sonra gezi düzenleyeceğini ve bu gezide müze rehberi olarak Mustafa'yı görevlendirdiğini sınıfa duyurmuştur. Mustafa'nın görevi, müzedeki eserlerin özelliklerini yansıtan bilgi notları hazırlamak ve gezi sırasında eserlerin daha iyi anlaşılması için açıklamalar yaparak arkadaşlarına yardım etmektir. Mustafa, verilen bu görevi hakkıyla yerine getirmek ve arkadaşlarına en iyi şekilde yardımcı olmak için gezi gününe kadar çok çalışmış ve en iyi şekilde hazırlanmıştır. Gezinin düzenleneceği gün, biraz geç kalmıştır, hızlı
} 
ve koşar adımlarla yetişmeye çalışırken, okulun önünde duran gezi otobüsünü görür. Tüm arkadaşları ve öğretmeni aracın içindedir ve araç hareket etmek üzeredir. Tam karşıdan karşlya geçmek üzereyken yaşlı bir bayan, Mustafa'nın kolundan tutarak "Bana yardım eder misiniz?" diye sorar. Mustafa'nın acelesi vardır, hemen gitmesi gerektiğini söylemek için döndüğ̈̈nde bayanın görme engelli olduğunu fark eder. Görme engelli bayan, eczaneye gitmek istediğini söyler. Eczane ile okul birbirlerine ters istikamettedir. Trafiğin yoğun olduğu bu caddede onu yalnız başına bırakmak istememektedir, ama ĕger ona yardım ederse büyük bir ihtimalle gezi otobüsünü kaçıracak, hem öğretmenini hayal kırıklı̆̆ına uğratacak hem de arkadaşlarına yardım edemeyecektir. Bu gün için çok hazırlanmıştır ama görme engelli bayanı orada bırakırsa vicdan azabı çekecektir. Siz Mustafa'nın yerinde olsaydınız ne yapardınız? Ahlaki yönden yaptı̆̆ınız eylemin nedenini açıklayınız?

Tablo 1

Öğrencilerin "Ahlâki ikilem 1" ile ilgili verdikleri kararların gerekçeleri

\begin{tabular}{|c|c|c|}
\hline Tema & Kodlar & $f$ \\
\hline \multirow{4}{*}{$\begin{array}{c}\text { I. Düzey } \\
\text { “Gelenek Öncesi” }\end{array}$} & Daha sonra öğretmenimden af dilerdim & 4 \\
\hline & Daha önemli gördüğüm için yaşlı kadına yardım ederdim. & 2 \\
\hline & Yaşlı kadını tanımadığım için & 1 \\
\hline & Toplam & 7 \\
\hline \multirow{7}{*}{$\begin{array}{l}\text { II. Düzey } \\
\text { “Geleneksel” }\end{array}$} & Vicdan azabı çekmemek için & 13 \\
\hline & Yaşlı birine yardım etmek için & 10 \\
\hline & Sözümü tutmasam pişman olurdum & 2 \\
\hline & Yardımsever olduğum için & 2 \\
\hline & Arkadaşlarım ve öğretmenim bana değer verdiği için & 1 \\
\hline & Vatandaşlık görevi olduğu için & 1 \\
\hline & Toplam & 29 \\
\hline \multirow{3}{*}{$\begin{array}{c}\text { III. Düzey } \\
\text { “Gelenek Sonrası" }\end{array}$} & Başka bir insanın hayatı söz konusu olduğu için & 7 \\
\hline & Verdiğim sözü yerine getirmek için & 1 \\
\hline & Toplam & 8 \\
\hline
\end{tabular}

Tablo 1'de görüldüğü gibi, öğrencilerin birinci ahlaki ikilemle ilgili cevaplarının gerekçeleri, üç ahlaki gelişim düzeyine uygun temalar altında toplanmıştır. Buna göre birinci temada 7, ikinci temada 29, üçüncü temada 8 gerekçe ortaya konmuştur. Öğrencilerden 13'ü verdikleri cevabın gerekçesi olarak "Vicdan azabı çekmemek için", 10’u "Yaşlı birine yardım etmek için”, 7'si "Başka bir insanın hayatı söz konusu olduğu için", 4'ü ise "Daha sonra öğretmenimden af dilerdim” şeklinde açıklamalar yapmışlardır.

Tablo 1'deki veriler doğrultusunda çalışma grubundaki öğrencilerin ortaya koydukları gerekçelerin genel olarak, zihinsel ve ahlaki gelişim seviyelerine de uygun şekilde II. Düzeyde yoğunlaştığı görülmüştür. Öğrencilerin, bırakıldıkları ikilem 
durumunda, ahlaki açıdan daha önemli gördükleri kararları verdikleri görülmüştür. Gerekçelere bakıldığında, genellikle kendi vicdani muhakemeleri üzerinde durdukları ve ahlaki ikilemin üstesinden gelmeye çalışırken kendi ahlaki değerlerini yoğun olarak düşündükleri anlaşılmaktadır.

Katılımcıların verdikleri cevaplardan örnekler: "Ĕ̆er yaşlı bayana yardım etmeseydim vicdan azabı yaşardım." (Ö38), “Ben olsam görme engelli bayana yardım ederdim. Çünkü yardım etmek bizim vatandaşlık görevimizdir.”(Ö24), “Ben olsaydım bayana yardım ederdim. Çünkü bir insanın canını tehlikeye atmaktan daha değerli değil ya. Vicdanım birisinin zarar görmesine karşı." (Ö19), "Yaşlı bayana yardım ederdim. Çünkü vicdan azabından iyidir." (Ö18), "Söz verip de tutmamak iyi bir şey değildir."

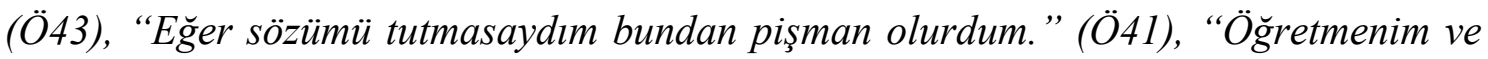
arkadaşlarım yardımsız kalırdı.” (Ö28), “Arkadaşlarıma yardım ederdim. Öğretmenime verdiğim sözü yerine getirirdim.” (Ö12).

\section{Ahlaki İkilem 2 (Yardımseverlik 2)}

Zerrin, çok iyi bir üniversitenin Tıp fakültesinde son sınıf öğrencisidir. Aynı zamanda oda arkadaşı olan en yakın arkadaşıyla birlikte bitirme sınavına haftalar öncesinden hazırlanmaya başlar. Fakat arkadaşı talihsiz bir şekilde rahatsızlanır ve iki hafta süreliğine hastanede yatması gerekir. Zerrin bu duruma çok üzülür ama sınava çok iyi hazırlanır. İki hafta sonra arkadaşının iyileşip hastaneden çıktığı gün aynı zamanda sınav günüdür. Arkadaşı sınava hiç hazırlanamamıştır, bu yüzden sınavda kendisine yardım etmesini ister. Çünkü eğer sinavdan geçemezse hem okulu bir yll uzayacak hem de aldiğ burs kesilecektir. Zerrin, bursu olmadan okula devam etmesi imkânsız olan arkadaşının zorluklar içerisinde okumasına karşın çok iyi bir tıp öğrencisi olduğunu bilmektedir. Arkadaşı ĕ̆er ona sınavda yardımcı olursa ögrenemediği ders konularını daha sonra eksiksiz olarak ögreneceği konusunda Zerrin'e söz verir. Zerrin çok yardımsever birisi olmasının yanı sıra arkadaşına değer vermektedir. Ama kurallara tamamen bağll biridir ve asla kopya verecek veya kopya çekecek bir insan değildir. Zerrin ve arkadaşı sınava girerler. Zerrin sınavını bitirir ve tam puan alacă̆ından emindir, gözetmen o yöne bakmamaktadır. Arkadaşı kâğıtlarını değiştirmelerini ister ve ondan son kez yardım ister. Siz Zerrin'in yerinde olsaydınız ne yapardınız? Ahlaki yönden yaptı̆̆ınız eylemin nedenini açıklayınız? 
Tablo 2

Öğrencilerin “Ahlâki ikilem 2" ile ilgili verdikleri kararların gerekçeleri

\begin{tabular}{|c|c|c|}
\hline Tema & Kodlar & $f$ \\
\hline \multirow{6}{*}{$\begin{array}{c}\text { I. Düzey } \\
\text { “Gelenek Öncesi” }\end{array}$} & Daha önceden çalışması gerekirdi & 3 \\
\hline & Kendimi korumak için & 2 \\
\hline & Gözetmen o tarafa bakmadığg için & 1 \\
\hline & Kopyacı durumuna düşmemek için & 1 \\
\hline & Arkadaşıma güvenmezdim & 1 \\
\hline & Toplam & 8 \\
\hline \multirow{9}{*}{$\begin{array}{c}\text { II. Düzey } \\
\text { “Geleneksel” }\end{array}$} & Arkadaşımın sözüne güvendiğim için & 7 \\
\hline & Vicdanım el vermez & 5 \\
\hline & Arkadaşıma yardım etmek için & 5 \\
\hline & Arkadaşımı korumak için & 4 \\
\hline & Arkadaşımı sevdiğim için & 4 \\
\hline & Arkadaşımı kaybetmemek için & 3 \\
\hline & Aynı durumda olsam arkadaşım da aynı şeyi yapardı & 1 \\
\hline & Öğretmenden yardım isterdim & 1 \\
\hline & Toplam & 28 \\
\hline \multirow{3}{*}{$\begin{array}{c}\text { III. Düzey } \\
\text { “Gelenek Sonrası” }\end{array}$} & Başkalarının hakkını yememek için & 5 \\
\hline & Sahip olduğum ahlaki değerlere aykırı olduğu için & 1 \\
\hline & Toplam & 6 \\
\hline
\end{tabular}

Tablo 2’de görüldüğü gibi, öğrencilerin ikinci ahlaki ikilemle ilgili cevaplarının gerekçeleri, üç ahlaki gelişim düzeyine uygun temalar altında toplanmıştır. Buna göre birinci temada 8, ikinci temada 28, üçüncü temada 6 gerekçe ortaya konmuştur. Öğrencilerden 7'si verdikleri cevabın gerekçesi olarak “Arkadaşımın sözüne güvendiğim için", 5’i “Arkadaşıma yardım etmek için”, 5’i "Başkalarının hakkını yememek için" şeklinde açıklamalar yapmışlardır.

Tablo 2'deki veriler doğrultusunda çalışma grubundaki öğrencilerin bırakıldıkları ikilem durumunda, karar verirken genellikle II. Düzeye uygun gerekçelere bağlı kaldıkları, bunun yanı sıra başkalarının nasıl düşündügünü göz önüne aldıkları görülmüştür. Yaptıkları gerekçelendirmelerin her üç temada çeşitlilik göstermesi, verdikleri kararlarda zorlandıkları göstermektedir.

Katılımcıların verdikleri cevaplardan örnekler: "Kopya verirdim. Çünkü gözetmen o tarafa bakmıyor." (Ö20), "Ben olsam kopya verirdim. Çünkü vicdanım arkadaşımın sınıfta kalmasına izin vermez.” (Ö19), “Kopya verirdim. Çünkü o benim en iyi arkadaşım." (Ö6), "Ben olsaydım arkadaşıma yardım ederdim. Çünkü arkadaşım okuldan atılacak buna benim vicdanım el vermez. (Ö4). "Kopya verirdim. Çünkü 
arkadaşımın hayatı kayarsa ömür boyu vicdan azabıyla yaşayacaktım.” (Ö8), “Ben olsam kopya vermezdim. Sinavi kazanamasa veya bursu kesilse de maddi durumu için ona yardım ederdim." (Ö17), "Ben onun yerinde olsam kopya vermezdim. O zaman ögretmenlerime ve diğer arkadaşlarıma kötülük etmiş olurdum." (Ö15), “Arkadaşıma kopya vermezdim. Çünkü tekrar çalışacağına söz veriyor ama hadi çalışmazsa.” (Ö13), "Ben olsaydım kopya vermezdim. Çünkü kopya verirsem başkalarının hakkını yemiş olurdum.” (Ö1).

\footnotetext{
Ahlaki İkilem 3 (Sorumluluk 1)

Anne babalarını bir trafik kazasında kaybetmiş olan iki kardeşten Ahmet, sekizinci, Melih ise altınc sınıf ögrencisidir. Her ikisi de ayn yatılı okulda okumaktadırlar. Ahmet, sorumluluk sahibi, çalışkan ve düşünceli bir çocuk olmasına karşın kardeşi Melih, özünde iyi bir çocuk olmasına rağmen biraz tembel biraz haylaz ve şaka yapmayı çok seven bir çocuktur. Ayrıca Melih'in bir kan hastalı̆̆ vardır. Bu yüzden zaylf ve güçsüzdür. Sık sık hastalandı̆̆ için kendisine dikkat etmesi gerekmektedir. Ahmet'se kardeşinin aksine güçlü ve săglıklı bir çocuktur. Kardeşini de çok sevmekte ve onu her yerde, her zaman korumaktadır adeta kardeşinin sorumluluğunu yüklenmiştir. Bir gün Melih, şaka olsun diye yemekhaneye girer. $O$ akşam yemeği için hazırlanmış olan çorbaya çok fazla miktarda karabiber döker. Bunu Ahmet dışında hiç kimse görmez. Ahmet kardeşinin çorbaya karabiber karıştırdığını gördüğ̈̈nde onu engellemek için geç kalmıştır ve bunu aşçıya söyleyemez. Yemekhanede çorbalar dă̆ıtıldığında herkes ilk kaşıkta hapşırmaya ve öksürmeye başlar. Bunu gören aşçı şaşkındır, çorbaya karabiberi kendisinin koymadığını söyler. Çocukların biri karabiber yüzünden astım krizine girer ve hastaneye kaldırllır. Okul idaresi, olaydan ötürü çok kızgındır ve suçlunun kim olduğunu araştırmaya başlar. Kamera kayıtlarına bakılır. Mutfăga girenin Melih olduğu anlaşılmak üzeredir. Ahmet, kardeşinin okuldan uzaklaştırma cezası alacă̆ına emindir. Ama okuldan uzaklaştırılırsa eve gönderilecektir. Orada ona bakacak sadece anneannesi vardır. O yaşlıdır ve kendi kendisine bile zor bakmaktadır. Oysa Melih'in iyi beslenmesi, üşütmemesi ve ilaçlarını düzenli kullanması gerekmektedir. Ahmet, kardeşinden sorumlu olduğunu ve onun suçunu üstlenmesi gerektiğini düşünmektedir. Ne de olsa kendisi güçlü ve sağlıklıdır. Fakat bu durumda büyük ihtimalle disiplin cezası alacak ve çok istediği askeri okula gitme şansını kaybedecektir. Siz Ahmet'in yerinde olsaydınız ne yapardınız? Ahlaki yönden yaptığınız eylemin nedenini açıklayınız?
} 
Tablo 3

Öğrencilerin “Ahlâki ikilem 3” ile ilgili verdikleri kararların gerekçeleri

\begin{tabular}{|c|c|c|}
\hline Tema & Kodlar & $f$ \\
\hline \multirow{6}{*}{$\begin{array}{c}\text { I. Düzey } \\
\text { “Gelenek Öncesi” }\end{array}$} & Kendi geleceğimi düşünürdüm & 2 \\
\hline & Kendi suçunu üstlenmesi gerekir & 2 \\
\hline & Yetkililerden af dilerim & 1 \\
\hline & Kendi başımın yanmasını istemem & 1 \\
\hline & Herkes yaptığı suçun cezasını çekmelidir & 1 \\
\hline & Toplam & 7 \\
\hline \multirow{8}{*}{$\begin{array}{c}\text { II. Düzey } \\
\text { “Geleneksel” }\end{array}$} & Kardeşimi korumak için & 14 \\
\hline & Kardeşimi sevdiğim için & 9 \\
\hline & Kardeşimin sorumluluğunu üstlenirdim & 5 \\
\hline & Kendi sorumluluklarını yerine getirmesi gerekir & 3 \\
\hline & Askeri okul kardeşimden önemli değil & 2 \\
\hline & Başka bir meslek sahibi olabilirim & 1 \\
\hline & Kardeşim hasta olduğu için & 1 \\
\hline & Toplam & 35 \\
\hline \multirow{3}{*}{$\begin{array}{c}\text { III. Düzey } \\
\text { “"Gelenek Sonrası” }\end{array}$} & Başka bir insanın hakkının yenmesi doğru değil & 1 \\
\hline & Başka bir insanın hayatını tehlikeye atmaması gerekir & 1 \\
\hline & Toplam & 2 \\
\hline
\end{tabular}

Tablo 3’te görüldüğü gibi, öğrencilerin üçüncü ahlaki ikilemle ilgili cevaplarının gerekçeleri, üç ahlaki gelişim düzeyine uygun temalar altında toplanmıştır. Buna göre birinci temada 7, ikinci temada 35, üçüncü temada 2 gerekçe ortaya konmuştur. Öğrencilerden 14'ü verdikleri cevabın gerekçesi olarak “Kardeşimi korumak için”, 9'u "Kardeşimi sevdiğim için”, 5’i “Kardeşimin sorumluluğunu üstlenirdim”, 3'ü "Kendi sorumluluklarını yerine getirmesi gerekir" şeklinde açıklamalar yapmışlardır.

Tablo 3'teki veriler doğrultusunda çalışma grubundaki öğrencilerin verdikleri cevapların büyük oranda II. Düzeyde toplandığı görülmektedir. Öğrenciler, bırakıldıkları ikilem durumunda, karar verirken genellikle kardeş sevgisinden etkilendikleri ve sahip oldukları kardeşlerini korumaya yönelik seçimler yaptıkları anlaşılmaktadır. Ayrıca, mevcut durum zor olsa da başka bir insanın sorumluluğunu üzerlerine almaya çalıştıkları görülmektedir.

Katılımcıların verdikleri cevaplardan örnekler: "Ben suçu üstlenirdim. Çünkü nede olsa o benim kardeşim, başka bir meslek sahibi olabilirim ama kardeşimin hastalı̆̆ için onu korurdum.” (Ö39). "Ben onun yerinde olsam kardeşim için elimden gelen her şeyi yapardım. Çünkü kardeşimin ne olursa olsun okuldan uzaklaştırllmasını istemezdim ve kardeşimin suçunu üstlenirdim." (Ö37), “Ben olsam kardeşimi çok 
sevdiğim için askeri okula gitmekten vazgeçerdim, bu yüzden onu korurdum." (A36), "Ben olsaydım suçu üstlenirdin ve başka bir mesleğe yönelirdim. Çünkü kardeşimi kaybedersem yalnız kalırdım.” (Ö26), "Ben olsam suçu üstlenirdim, çünkü kardeşimi her zaman korurum ve kollarım, çünkü kardeşim hasta ve onun sağlı̆̆ına dikkat edilmeli, bu durumda ben yardım ederdim." (Ö19), "Ben olsaydım kardeşimin suçunu üstlenmezdim. Çünkü artık onun sorumluluk alma zamanı gelmiştir.” (Ö41), “ Ben olsaydım askeri okulu seçerdim. Kendi hayatımı düşünerek devam ederdim.” (Ö40), "Başkasının hakkını yediği için kardeşimin suçunu üstlenmezdim, çünkü bu doğru bir şey değil” (Ö32), "Ben olsaydım kardeşimin suçunu üstlenmezdim çünkü herkes yaptığ suçun cezasını çekmelidir.” (Ö29), "Ben olsaydım yetkililere her şeyi anladır, kardeşim için onlardan af dilerdim." (Ö4).

\begin{abstract}
Ahlaki İkilem (Sorumluluk 2)
Elif, sekizinci sınıf öğrencisidir. Ailesi o henüz küçük bir çocukken köyden şehre göç etmişlerdir. Beş çocuğu olan ailenin okuldaki başarılı olan tek evladı Elif'tir. Fakat Elif'in babası onun sekizinci sınıftan sonra okula devam etmesine razı değildir. Elif’i mümkün olan en kısa sürede evlendirmeyi düşünmektedir. Ona göre kız çocuklarının okuması gereksizdir. Evlenmeyi değil de okumayı ve meslek sahibi olmayı isteyen Elif, çalışkan ve zeki bir öğrenci olmasına rağmen babasını bir türlü razı edememektedir. Babasını razı etmek için sınıf ögretmeninden yardım ister. Sınıf ögretmeni Elif'in babasını okula çă̆ırır ve onu ikna etmeye çalışır; Elif'in ne kadar başarılı olduğunu ve gelecekte çok iyi şeyler başarabileceğini duyunca, babası kızı hakkında içten içe gurur duymaya başlamıştır. Ama hemen kabul etmemeye kararlıdır. Elif'i liseye gönderebilmesi için onun sene sonunda okul birincisi olma koşulunu öne sürer. Elif ĕger okul birincisi olursa onu liseye gönderecektir. Ĕ̆er o yul herhangi bir dersten düşük not alırsa onu liseye göndermeyecektir. Öğretmen Elif'in çok çalışacă̆ına ve başaracă̆ına emindir. Fakat sınıf öğretmeninin bilmediği bir sorun vardır. Elif, iki gün önce Matematik ögretmeninin sınıfa kızmasından ötürü beklemediği bir anda yaptı̆̆ sınavdan ilk kez zaylf almıştır. Babasıyla öğretmenin görüşmesi bittikten ve onlar anlaştıktan sonra Elif, kara kara düşünmeye başlar. Matematik öğretmeni oldukça sert ve kuralcı bir öğretmendir. Bu sinavı değiştirmesinin ya da notu yükseltmesinin imkânı yoktur. Fakat ertesi gün Elif, teneffüse çıktıklarında matematik öğretmeninin çantasını sınıfta bıraktı̆̆ını fark eder. Çantada not defteri de vardır ve sınıf bomboştur. Elif, hiç kimse görmeden not defterini çantadan alıp imha eder. O gün sınıf nöbetçisi, sınıfin en haylaz ögrencisi olan Çağlar'dır. Matematik öğretmeni bunu Çağlar'ın yaptığına inanmaktadır. Çağlar'ın daha önceden işlediği suçlar da göz önünde bulundurularak onun okuldan atılmasına karar verilir. Bunu duyan Elif şaşkındır. Kendini sorumluluk sahibi birisi olarak gören Elif, hem kendine karşı eğitimine devam etme sorumluluğu vardır hem de suçsuz bir insanın cezalandırlmasını engelleme sorumluluğu. Siz Elif'in yerinde olsaydınız ne yapardınız? Ahlaki yönden yaptı̆̆ınız eylemin nedenini açıklayınız?
\end{abstract}


Tablo 4

Öğrencilerin “Ahlâki ikilem 4" ile ilgili verdikleri kararların gerekçeleri

\begin{tabular}{|c|c|c|}
\hline Tema & Kodlar & $f$ \\
\hline \multirow{6}{*}{$\begin{array}{c}\text { I. Düzey } \\
\text { “Gelenek Öncesi” }\end{array}$} & Yanlış bir davranıştan kaçınmak için & 4 \\
\hline & Eğitimime devam etmek için & 4 \\
\hline & Kendi geleceğimi düşünürdüm & 1 \\
\hline & Hayatım benim için önemli & 1 \\
\hline & Suçlanan kişi zaten bunu hak ediyor & 1 \\
\hline & Toplam & 11 \\
\hline \multirow{7}{*}{$\begin{array}{l}\text { II. Düzey } \\
\text { “Geleneksel” }\end{array}$} & Suçsuz birinin ceza almasını istemezdim & 11 \\
\hline & Vicdan azabı çekerdim & 7 \\
\hline & Yaptığım şeyin sorumluluğunu üzerime alırdım & 6 \\
\hline & Başka bir insana iftira atmamak için & 3 \\
\hline & Ahlâklı biri olmayı istediğim için & 2 \\
\hline & Suçlu sonunda ortaya çıkacaktır & 1 \\
\hline & Toplam & 30 \\
\hline \multirow{3}{*}{$\begin{array}{c}\text { III. Düzey } \\
\text { “"Gelenek Sonrası” }\end{array}$} & Başkalarının hakkına girmek doğru olmaz & 2 \\
\hline & Başka bir insanın hayatını mahvedemem & 1 \\
\hline & Toplam & 3 \\
\hline
\end{tabular}

Tablo 4'te görüldüğü gibi, öğrencilerin dördüncü ahlaki ikilemle ilgili cevaplarının gerekçeleri kodlanırken, verilen cevaplar; üç ahlaki gelişim düzeyine uygun temalar altında toplanmıştır. Buna göre birinci temada 11, ikinci temada 30, üçüncü temada 3 gerekçe ortaya konmuştur. Öğrencilerden 11'i verdikleri cevabın gerekçesi olarak "Suçsuz birinin ceza almasını istemezdim", 7'si "Vicdan azabı çekerdim”, 6'sı "Yaptığım şeyin sorumluluğunu üzerime alırdım”, şeklinde açıklamalar yapmışlardır.

Tablo 4'teki veriler doğrultusunda çalışma grubundaki öğrencilerin bırakıldıkları ikilem durumunda, karar verirken genellikle başka birini suçlanmaktan ve vicdan azabı çekmekten kaçınmak için seçimler yaptıkları anlaşılmaktadır. Ayrıca, öğrencilerin verdikleri cevaplara bakıldığında en çok II. Düzeyde yoğunlaşsa da, I. Düzeyde verilen cevapların artış gösterdiği görülmüştür. Bunun nedeni kalımcıların karar verirken sorumluluk değerini kendi çıkarlarının önünde tutmakta zorluk çekmeleridir.

Katılımcıların verdikleri cevaplardan örnekler: "İtiraf ederdim, çünkü masum birinin ceza almasına göz yumamazdım.” (Ö43), “Ben olsam suçumu açıklarım çünkü buna vicdanım el vermez” (Ö25), "Ben olsaydım yaptığım şeyi söylerdim, çünkü suçsuz yere birisi ceza alacak, ben de hak ettiğimi almalıydım." (Ö35), "Suçu kabullenirdim, aksi halde arkadaşım ceza alır, benim vicdanım rahat etmezdi." (Ö37), "Suçsuz birinin 
benim yerime ceza almasını istemezdim, bu yüzden söylerdim." (Ö19), "Ben olsaydım suçu itiraf etmezdim, okuyup bir şeyler olmak istediğim için." (Ö40), "Ben olsaydım suçlunun kendim olduğunu söylemezdim çünkü zaten o arkadaşımız çok şımarık ve suçlu birisiymiş, bu yüzden hak ettiğini düşünürdüm." (Ö42), "Ben hiçbir şey yapmazdım çünkü söylersem okula gitme şansım kalmazdl.” (Ö20), “Öğretmene söylemezdim, çünkü kendi geleceğimi düşünürdüm.”(Ö13).

\begin{abstract}
Ahlaki İkilem 5 (Doğal çevreye duyarlılık 1)
Ayşegül, soyu tükenmiş hayvanları inceleyen bir bilim insanıdır. Çok uzun süredir kılıç dişli kaplan isminde bir yırtıcı üzerinde çalışmalarda bulunmaktadır. Yapılan araştırmalar bu hayvanın türünün 10 bin yıl önce tükendiğini göstermektedir. Bu hayvana ait fosiller üzerinde çalışan Ayşegül, Büyük Okyanus'ta yer alan çok küçük bir adada bu hayvanın hala yaşıyor olabileceğine dair ipuçları bulur. Ömrünün son yirmi yılını bu araştırmalara adayan Ayşegül, bu deniz yolculuğunu yapmaya ve eğer hala yaşlyorsa bunu tüm dünyaya göstermeye karar verir. Haftalar süren deniz yolculuğu sonrasında adaya yaklaşmışlardır. Fakat büyük bir firtına çıkar ve gemi batar. Ayşegül uyandı̆̆ında sahilde kumlar üzerinde yatmaktadır ve gemi kazasından kurtulan kendinden başka kimse yoktur. Biraz kendine geldiğinde gemiden sahile vuran enkaz parçalarında işine yarayabilecek bir şeyler arar ve bir kutunun içinde bir tabanca bulur. Kendini herhangi bir tehlikeden korumak için tabancayı alır ve adayı keşfe koyulur. Birkaç saat boyunca gezindikten sonra neredeyse adanın tümünü aramıştır ama aradı̆̆ hayvanın izine rastlamamıştır. Son olarak sahile bakan yamaçlardaki kaya oyuklarına yönelir. Büyük bir kaya oluğuna girer içeride aradiğı kılıç dişli kaplanları bulur. Üç yavru kaplan ve yanlarında anneleri olduğu anlaşılan bir dişi kaplan yatmaktadır, fakat hepsi firtınada okyanusun yükselmesinden dolayı boğularak ölmüştür. Ama yanlış olan bir şey vardır, bu son kalan kılıç dişli kaplan ailesinin erkek üyesi nerededir. Ayşegül arkasını döndüğünde muhtemelen dünyada son kalan kılıç dişli kaplan ile karşı karşıyadır. Hayvan oldukça saldırgan görünmektedir ve Ayşegül'e doğru hırlayarak yaklaşmaktadır. Ayşegül'ün kaçacak yeri yoktur çünkü kaplan mağaranın girişinde durmaktadır. Ayşegül birden gemi kalıntılarından bulduğu tabancay cebinden çıkarır ve hayatı boyunca bulmaya çalıştığı kılıç dişli kaplan'a yöneltir. Ĕger onu öldürürse büyük olasılıkla kendi elleriyle türün yaşayan son örneğini ortadan kaldırmış olacaktır. Tüm hayatını onu bulmaya adamıştır, doğal çevreye zarar vermektense ölmeyi tercih edebilecek bir kişidir ama ölürse belki de bu hayvana yardım edebilecek son kişi de ortadan kalkmış olacaktır. Ĕger ateş etmezse bunu canıyla ödeyecektir. Siz Ayşegül'ün yerinde olsaydınız ne yapardınız? Ahlaki yönden yaptığınız eylemin nedenini açıklayınız?
\end{abstract}


Tablo 5

Öğrencilerin “Ahlâki ikilem 5” ile ilgili verdikleri kararların gerekçeleri

\begin{tabular}{|c|c|c|}
\hline Tema & Kodlar & $f$ \\
\hline \multirow{4}{*}{$\begin{array}{c}\text { I. Düzey } \\
\text { “Gelenek Öncesi” }\end{array}$} & Hayatım daha önemlidir & 12 \\
\hline & Kendi canımı tehlikeye atmazdım & 7 \\
\hline & Zarar görmekten korunmak için & 2 \\
\hline & Toplam & 21 \\
\hline \multirow{4}{*}{$\begin{array}{c}\text { II. Düzey } \\
\text { “Geleneksel” }\end{array}$} & Doğayı korumak ve türün yok olmasını engellemek için & 14 \\
\hline & Vicdanım elvermezdi & 3 \\
\hline & Adım tarihe geçerdi & 1 \\
\hline & Toplam & 18 \\
\hline \multirow{3}{*}{$\begin{array}{c}\text { III. Düzey } \\
\text { “Gelenek Sonrası" }\end{array}$} & Hayatımı bu işe adadığım için & 4 \\
\hline & Ne olursa olsun bir cana kıyamam & 1 \\
\hline & Toplam & 5 \\
\hline
\end{tabular}

Tablo 5'te görüldüğü gibi, öğrencilerin beşinci ahlaki ikilemle ilgili cevaplarının gerekçeleri kodlanırken, verilen cevaplar; üç ahlaki gelişim düzeyine uygun temalar altında toplanmıştır. Buna göre birinci temada 21, ikinci temada 18, üçüncü temada 5 gerekçe ortaya konmuştur. Öğrencilerden 14'ü verdikleri cevabın gerekçesi olarak "Doğayı korumak ve türün yok olmasını engellemek için", 12'si "Hayatım daha önemlidir", 7'si "Kendi canımı tehlikeye atmazdım", 4'ü "Hayatımı bu işe adadığım için”, şeklinde açıklamalar yapmışlardır.

Tablo 5'teki veriler doğrultusunda çalışma grubundaki öğrencilerin bırakıldıkları ikilem durumunda, verdikleri cevapların I. Düzeyde yoğunlaştığı görülmektedir. Bunun nedeni verilen ikilemde ilgili değerin insanın kendi hayatıyla kıyaslanmasından kaynaklanmaktadır. Yapılan gerekçelerin bu durumu destekler nitelikte olduğu anlaşılmaktadır. Ayrıca öğrencilerin büyük bir bölümünün ikilemden hareketle doğal çevreye duyarlılık değeriyle kendi hayatlarını kıyasladıkları görülmüştür.

Katılımcıların verdikleri cevaplardan örnekler: "Ben onun yerinde olsam hayvanı öldürmezdim. Çünkü doğal çevreye zarar vermek istemem.” (Ö44), “Çevreye zarar vermektense ölmeyi tercih ederim” (Ö37), "Araştırmacı bu türü bulmak için tüm hayatını vermişstir. Bu yüzden öldürmemelidir”(Ö29), “Ben araştırmacının yerinde olsam canımı feda ederdim ve böylece adım tarihe geçerdi" (Ö28), "Ben hayvanı öldürmezdim ve kendimi doğal çevre için feda ederdim, ne olursa olsun bir hayvanın canına klyamam (Ö26), "Ben olsaydım hayvanı öldürürdüm. Çünkü kendi canım ortada. Benim canım hayvanınkinden daha önemlidir.”(Ö42), "Hayvanı öldürürdüm. Çünkü ölürsem arkamda ailem ve sevdiklerim kalacak” (Ö23), “Ateş ederdim. Çünkü eğer ateş etmezsem o beni öldürecekti, o yüzden vururdum ve canımı kurtarırdım." 
(Ö14), "Ben olsaydım hayvanı öldürürdüm. Çünkü benim hayatım kesinlikle daha önemlidir.” (Ö5).

\begin{abstract}
Ahlaki İkilem 6 (Doğal çevreye duyarlılık 2)
İhsan Bey emekli bir öğretmendir. Hayatın öğrencilerine adamış ve onlara faydalı olmak için elinden geleni yapmıştır. Onun en önemli özelliği ise doğaya olan düşkünlü̆ü̈dür. Özellikle, ağaçlart seven ve çevrenin ağaçlandırılmasını isteyen İhsan ögretmen, bin bir güçlükle aldı̆ğ bir araziyi ögrencileri ile birlikte ağaçlandırmış ve devlet tarafindan da ödüllendirilmiş̧tir. Emeklilik günlerinde de bu küçük korulukta ağaçların bakımıyla ilgilenmektedir. Üstelik koruluğa diktiği ağaçlarda ender bir kuş türü de yuva kurmuş ve bu korulukta bir kuş cenneti kendiliğinden oluşmuştur. Bu yüzden de çevreciler İhsan Bey'i ödüllendirmiştir. İhsan ögretmen, hayattaki tek varlığı olan bu ağaçlık alan sayesinde doğaya bir faydası olduğunu düşünüp emeklilik günlerini mutluluk içinde geçirmektedir. Fakat bir gün araziye birtakım yabancı adamlar gelir. Bu koruluğun arazisi önceden pek değerli bir arazi değilken zaman içinde şehrin büyümesi ile değer kazanmıştır. Gelen adamlar araziyi satın almak için İhsan Bey'le görüşürler. Buraya bir alışveriş merkezi yapmayı planlamaktadırlar. İhsan Bey bunu asla kabul etmeyeceğini söyler. Yıllardır emek verdiği bu ağaçların kesilmesini istememektedir. Teklif edilen para oldukça yüksektir. Fakat İhsan Bey için para önemsizdir. Hatta ölmeden önce araziyi devlete bağışlamayı bile düşünmektedir. Kısa bir süre sonra, İhsan Bey ansızın hastalanır. Doktor, onun önemli bir ameliyat olması gerektiğini, sonrasında da uzun bir tedavi süreci olduğunu söyler. Bunun için yurt dışına gitmesi gerekmektedir. Bu da oldukça pahalıdır. İhsan Bey'in bu kadar parası yoktur. Ama ağaçlandırdı̆̆ araziyi satarsa alacağ para, tedavi için yeterli olacaktır. İhsan Bey, öğrencileriyle birlikte diktiği, severek yetiştirdiği bu ağaçların kesilmesini istememektedir. Üstelik kuşlara ne olacaktır? Ona göre, bütün ömrünce yaptığı en iyi şey budur. Herkesin ona saygı ve sevgi duymasını sağlamıştır. Ama günden güne hastalığının ilerlediğini hissetmektedir. Siz İhsan Bey'in yerinde olsaydınız ne yapardınız? Ahlaki yönden yaptığınız eylemin nedenini açıklayınız?
\end{abstract}

Tablo 6

Öğrencilerin "Ahlâki ikilem 6” ile ilgili verdikleri kararların gerekçeleri

\begin{tabular}{clc}
\hline Tema & \multicolumn{1}{c}{ Kodlar } & $\boldsymbol{f}$ \\
\hline \multirow{2}{*}{$\begin{array}{c}\text { I. Düzey } \\
\text { “Gelenek Öncesi” }\end{array}$} & Sağlığım daha önemlidir & 12 \\
& Elimatım her şeyden önemlidir başka bir şey gelmediği için & 9 \\
& Toplam & 1 \\
II. Düzey & Doğaya zarar vermemek için & $\mathbf{2 2}$ \\
\hline “Geleneksel” & Emek verdiğim iç̧in & 13 \\
& Öğrencileri hayal kırıklığına uğratmamak için & 4 \\
& Toplam & 1 \\
III. Düzey & Daha çok yeşil alan yaratabilmek için & $\mathbf{1 8}$ \\
\hline "Gelenek Sonrası” & Çevreyi güzelleştirmek için & 2 \\
& Toplam & 2 \\
\hline
\end{tabular}

(c) 2014 AKU, Kuramsal Eğitimbilim Dergisi - Journal of Theoretical Educational Science, 7(3), 383-407 
Tablo 6'da görüldüğü gibi, öğrencilerin altıncı ahlaki ikilemle ilgili cevaplarının gerekçeleri kodlanırken, verilen cevaplar; üç ahlaki gelişim düzeyine uygun temalar altında toplanmıştır. Buna göre birinci temada 22, ikinci temada 18, üçüncü temada 4 gerekçe ortaya konmuştur. Öğrencilerden 13'ü verdikleri cevabın gerekçesi olarak "Doğaya zarar vermemek için”, 12'si "Sağlığım daha önemlidir”, 9'u "Hayatım her şeyden önemlidir”, 4'ü “Emek verdiğim için”, şeklinde açıklamalar yapmışlardır.

Tablo 6'daki veriler doğrultusunda çalışma grubundaki öğrencilerin bırakıldıkları ikilem durumunda, verilen cevapların her iki temaya orantılı bir şekilde dağıldığı görülmekte, hatta verilen ikilemin de etkisiyle öğrencilerin verilen değere, daha çok olumsuz yönde kararlar bildirdiği görülmektedir. Bunun nedeni öğrencilerin kendi hayatlarıyla verilen değeri kıyaslamalarıdır. Öğrencilerin, kendi hayatlarını feda etme noktasında büyük kararsızlık yaşadıkları görülmüştür.

Katılımcıların verdikleri cevaplardan örnekler: "Ben olsaydım ölmeyi tercih ederdim. Çünkü doğanın yok olmasına vicdanım el vermez. Azap çekerim.” (Ö3), "Araziyi satmazdım. Çünkü canlılar ölecek ve kuşlar yuvasız kalacaktır. Ben bu işe razı olamazdım ve araziyi satmazdım." (Ö14), "Ben olsam araziyi vermezdim. Çünkü nede olsa bir gün öleceğim. Artık doğa kötüye gidiyor. Bu yüzden doğaya bir katkım olsun derdim.” (Ö21), "Ben olsaydım satmazdım. Çünkü hem çevre zarar görecek hem de diktiğim ă̆açlar yok olacaktır. Ödülleri de boşuna almış olurum. Hastalık önemli değil. O ă̆açlar bizim oksijen kaynă̆ımızdır. Hem orası hayvanların evidir.” (Ö24), “Ben araziyi satardım. Çünkü satmazsam ölebilirim. Bu yüzden araziyi satar ve iyileşirdim. Herkesin bana sevgi ve saygı duyması să̆lı̆̆ımdan önemli değil." (Ö7), "Ben onun yerinde olsam araziyi satardım. Çünkü să̆lı̆̆ım yeşil bir alandan daha önemli.” (Ö12), "Ben onun yerinde olsaydım satardım Çünkü en önemli olan şey hayattır." (Ö15), "Elimden bir şey gelmediği için satardım." (Ö16), "Ben satardım. Çünkü ĕger satmazsam öldükten sonra kime kalırsa o parayı duyunca satacaktır.” (Ö20). 


\section{Tablo 7}

Çalışma grubunun uygulamayla ilgili görüşleri

\begin{tabular}{llc}
\hline \multicolumn{1}{c}{ Tema } & \multicolumn{1}{c}{ Kodlar } & $\boldsymbol{f}$ \\
\hline & Vicdanımı düşünmemi sağladı & 7 \\
& Ahlaki değerlerimi düşünmemi sağladı & 6 \\
& Ahlaki yönden karar vermemi kolaylaştırdı & 4 \\
Ahlaki Değerlere İlgili & Beni ahlaki yönden çok etkiledi & 1 \\
& Bana sorumluluklarımı anlattı & 1 \\
& Ahlaki olarak doğruyu bulmamı sağladı & 1 \\
& Ahlaki yönden kendi seçimlerimi tartışmamı sağladı & 1 \\
& Toplam & $\mathbf{2 1}$ \\
\hline & Karar vermekte zorlandım & 14 \\
& Bana yaşam tecrübesi sağladı & 4 \\
& Seçim yapmakta zorlandığımı anladım & 2 \\
& Hikâyeleri çok yararlı buldum & 1 \\
& Hayatla mücadelenin zorluğunu gördüm & 1 \\
& Hayal gücümü genişletti & 1 \\
Toplam & $\mathbf{2 3}$ \\
\hline
\end{tabular}

Tablo 7 incelendiğinde, çalışma grubundaki öğrencilerin yapılan uygulamayla ilgili düşüncelerinin genel olarak olumlu olduğu görülmektedir. Öğrencilerin verdikleri cevaplar, iki tema altına toplanmıştır: "Ahlaki değerlerle ilgili", "Düşünce süreciyle ilgili”. Açıklamalar, iki temaya birbirine yakın şekilde dağılmıştır. Öğrencilerden 14'ü yapılan uygulamanın kendilerinde yarattı̆̆1 etkiyi "Karar vermekte zorlandım", 7'si "Vicdanımı düşünmemi sağladı", 6'sı “Ahlaki değerlerimi düşünmemi sağladı”, 4’ü "Ahlaki yönden karar vermemi kolaylaştırdı" şeklinde açıklamıştır. Yapılan açıklamalar, öğrencilerin ahlaki ikilem yönteminden memnun kaldıkları şeklinde yorumlanabilir.

\section{Sonuç ve Tartışma}

$\mathrm{Bu}$ araştırma ile Sosyal Bilgiler dersinde doğrudan verilecek değerlerden "sorumluluk, yardımseverlik ve doğal çevreye duyarlılık" değerleri seçilmiştir. Bu değerler Ahlaki ikilem yaklaşımına uygun bir şekilde öğrencilere verilmeye çalışılmış ve öğrencilerin farklı durumlarda neye dayanarak karar verdikleri incelenmiştir. Öğrenci cevapları(gerekçeleri) incelendiğinde seçilen değerlerin öğretiminde Ahlaki ikilem yaklaşımının olumlu yönde etkisinin olduğu söylenebilir.

Toplumsal yaşamda karşılaşılan durumlar, iyi ve kötü arasında bir seçim yapmak kadar kolay değildir. Komplike durumların üstesinden gelmek, daha karmaşık zihinsel 
süreçler gerektirir. Eğitim süreci içinde kazanılması beklenen değerlerin öğrencilere doğrudan öğretilmesi hususunda zorluk yaşanmaktadır. Öğrencilerin değerleri bilişsel boyutta öğrenmeleri ve sorulduğunda ilgili değeri savunmaları, kendi hayatlarında bu değerleri içselleştirdiklerini göstermemektedir. Sınıf ortamında öğrencilerin ahlaki ikilem durumlarında bırakılması, günlük hayatta bu değerleri nasıl kullanacakları ve ahlaki yargılarını derinlemesine düşünmesini sağlamaktadır. İkilem içinde bırakılan çocuk, kendi faydasını koruma veya genel ahlaki kurala uyma arasında kalır. Verdikleri farklı cevaplar, katılımcıların karar verirken çok çeşitli psikolojik faktörlerden etkilendiklerini göstermektedir. Özelikle gerekçelerine bakıldığında öğrencilerin verilen durumlar üzerine kapsamlı biçimde düşündükleri ve değer yargılarını sınadıkları görülmektedir. Öğrenciler genellikle içinde bulundukları gelişim seviyesine uygun olarak Kohlberg'in II. Ahlaki gelişim düzeyi olan "Geleneksel” düzeyde cevaplar vermişlerdir. Öğrencilerin verdikleri cevaplar ve ortaya koydukları gerekçelerin hangi düzeyde olduğu kadar, onların ahlaki muhakeme yoluna itilmesi ve sahip oldukları değerleri sınama firsatı bulmaları da önemlidir.

Çiftçi (2003)'e göre eğitimin amacı, belli düşünce biçimleri kazandırmak yerine geliştirmektir. Gelişim ancak, çocuk veya genç kendi belli zihinsel şemalarının yetersiz olduğunu fark ederse, olguları açıklamakta dengesizlik yaşarsa ve bunun neticesinde ahlaki odaklanmanın dönüşümü gerçekleşirse oluşabilir. Bu araştırmada verilen Ahlaki ikilemlerde de sözü edilen dengesizlik durumları yaratılmaya çalışılmış, öğrencilerin kendi ahlaki dönüşümlerini gerçekleştirmelerini sağlamak amaçlanmıştır. Nichols ve Mallon (2006) üniversite öğrencileriyle yaptıkları çalışmalarında katılımcıları ahlaki ikilemlerle karşı karşıya bırakmıştır. Bir eylemin yanlış olup olmadığıyla ilgili kurallar, duygusal tepkiler ve fayda değerlendirmeleri dahil bir dizi karmaşı psikolojik sürecin işe koyulduğunu ve düşünüldüğünü ortaya koymuşlardır. Bu araştırmada öğrencilerin verdikleri kararlarla ilgili gerekçelerde bu nitelikte bir görünümdedir. Ahlaki ikilem yaklaşımını kullanarak 5. sınıf öğrencileriyle çalışan Baydar (2009), öğrencilerin adil olma, sorumluluk, dayanışma ve tarihsel mirasa duyarlılık değerlerini kazanım düzeyleri Kohlberg'in ahlaki gelişim kuramına göre ikinci düzey olan geleneksel düzeyde yer aldığı sonucuna varmıştır. Bu sonuç araştırmamızı destekler niteliktedir. Yiğittir ve Kaymakçı (2012)'nın Sosyal Bilgiler öğretim programında yer alan etkinliklerin değer eğitimi yaklaşımlarına göre durumunu inceledikleri çalışmalarında 4., 5. ve 6. sınıfta Ahlaki muhakeme yaklaşımıyla ilgili hiç etkinliğe rastlanmamıştır. 7. sınıfta ise bu değer öğretimi yaklaşımıyla ilgili iki adet etkinlik bulunmuştur. Ayrıca Yazar ve Yelken (2013) öğretmen görüşleri üzerine yaptıkları araştırmalarında, öğretmenlerin değerleri kazandırmak için programdaki içeriğin zenginleştirilmesi gerektiği görüşünde birleştikleri görülmektedir. Bu veriler yaptığımız araştırmanın gerekliliğini destekler niteliktedir.

\section{Öneriler}

$\mathrm{Bu}$ araştırmadan elde edilen sonuçlara dayalı olarak şu öneriler getirilebilir: Ahlaki İkilem yaklaşımı, öğrencilere aldıkları kararların gerekçelerini sorguluma imkanı tanıdığı ve karmaşık zihinsel süreçleri deneyimleme firsatı tanıdığı için sosyal bilgiler 
dersinde verilecek değerlerin eğitiminde kullanılabilecek, uygun ve etkili bir yaklaşım olarak görülmektedir. Farklı sınıf düzeylerinde ve değişik konularda, bu yaklaşıma uygun çalışmalar yapılmalıdır. Sosyal Bilgiler dersinde işlenen konular değerler konusunda dolaylı bir eğitim sağlasa da doğrudan verilecek değerler hususunda daha belirgin etkinlikler düzenlenebilir. Sosyal Bilgiler öğretmenleri ve diğer branş öğretmenleri derslerinde fursat buldukça ahlaki gelişim ve değerler eğitimiyle ilgili bağlantılar kurabilir. Değerler eğitimi alanında farklı yaklaşımlara dayanan etkinliktemelli ve deneysel çalışmaların sayısı artırılmalıdır. 


\section{Kaynakça}

Akbaş, O. (2008). Değerler Eğitimi Akımlarına Genel Bir Bakış. Değerler Ĕ̆gitimi Dergisi, 6(16), 9-27.

Armstrong, D. G. (1980). Social Studies in Secondary Education. New York: Macmillan Publishing Co. Inc.

Aydın, M. Z. (2008). Okulda Ahlak Eğitimi ve Ahlak Öğretiminde Örnek Olay Incelemesi Yöntemi (3. bask1). Ankara: Nobel Yayın Dağıtım.

Balcı, N. (2008). Illköğretim 6. Sinıf Sosyal Bilgiler Dersinde Dĕger Ĕ̈itiminin Etkililiği (Yayınlanmamış yüksek lisans tezi). Marmara Üniversitesi, İstanbul.

Bandura, A. (1991). Social cognitive theory of moral thought and action. In W. M. Kurtines \& J. L. Gewirtz (Eds.), Handbook of moral behavior and development (Vol. 1, pp. 45-103). Hillsdale, NJ: Erlbaum.

Baydar, P. (2009). Illköğretim 5. Sınıf Sosyal Bilgiler Programında Belirlenen Değerlerin Kazanım Düzeyleri ve Bu Süreçte Yaşanan Soruların Değerlendirilmesi (Yayınlanmamış yüksek lisans tezi). Çukurova Üniversitesi, Adana.

Bull, N. J. (1969). Moral Judgement from Childhood to Adolescence. London: Routledge.

Colby, A., Kohlberg, L., Speicher, B., Hewer, A., Candee, D., Gibbs, J. \& Power, C. (1987). The Measurement of Moral Judgement, Volume I: Theoretical Foundations and Research Validation. UK: Cambridge University Press.

Çiftçi, N. (2003). Kohlberg'in Bilişsel Ahlâk Gelişimi Teorisi: Ahlâk ve Demokrasi Eğitimi. Değerler Ĕ̆itimi Dergisi. 1(1), 43-47.

Durkheim, E. (2002). Moral Education. (E. K. Wilson \& H. Schnurer, Trans.). (foreword by P. Fauconnet). Mineola, New York: Dover Publications, Inc. (Original work published 1961).

Greene, J. \& Haidt J. (2002). How (and where) does moral judgement work. Trends in Cognitive Sciences, 6(12), 517-523.

Halstead, J. M. \& Pike M. A. (2006). Citizenship and Moral Education. London and New York: Routledge.

Harding, C. G. (2010). Intention, Contradiction and the Recognition of Dilemmas. In C. G. Harding (Ed), Moral Dilemmas and Ethical Reasoning (pp. 43-55). New Brunswick and London: Transaction Publishers.

Karatay, H. (2011). Karakter Eğitiminde Edebi Eserlerin Kullanımı. Turkish Studies, 6(1), 1439-1454.

McConnell, T. (2010), Moral Dilemmas. In E. N. Zalta (Ed.), The Stanford Encyclopedia of Philosophy (Summer Ed.), Retrieved from http://plato.stanford.edu/archives/sum2010/entries/moral-dilemmas.

Nichols, S. \& Mallon, R. (2006). Moral Dilemmas and Moral Rules. Cognition, 100, 530-542. 
Piaget, J. (1932). The Moral Judgment of the Child. (M. Gabain, Trans.). Glencoe, Illinois: The Free Press. (Reprinted by Routledge).

Power, F. C., Higgins, A. \& Kohlberg L. (1989). Lawrence Kohlberg's Approach to Moral Education. New York: Columbia University Press.

Rosen, B. (1980). Moral Dilemmas and Their Treatment. In B. Munsey (Ed.). Moral Development, Moral Education and Kohlberg Basic Issues in Philosophy, Religion and Educaiton. Birmingham Alabama: Religious Education Press.

Sharma S. R. (2003). Encyclopaedia of Value and Moral Education (Vol. 5). New Delhi: Cosmo Publications.

Smetana, J. G. (2006). Social-Cognitive Domain Theory: Consistencies and Variations in Children's Moral and Social Judgments. In M. Killen \& J. G. Smetana (Eds.). Handbook of Moral Development. Mahwah, New Jersey: Lawrence Erlbaum Associates, Publishers.

Tavşancıl, E. Aslan, A. E. (2001). Sözel, Yazılı ve Diğer Materyaller İçin Iç̧erik Analizi ve Uygulama Örnekleri. İstanbul: Epsilon Yayıncilık.

Özgüven, İ. E. (1999). Psikolojik Testler. Ankara: Pdrem Yayınları.

Venkataiah, N. (2007). Value Education. New Delhi: APH Publishing Corporation.

Yazar, T. \& Yelken T. Y. (2013). İlköğretim Sosyal Bilgiler Programında Değerler Eğitiminin Mevcut Durumunun Öğretmen Görüşlerine Göre Belirlenmesi. Uluslararasi Avrasya Sosyal Bilimler Dergisi, 4(10). 44-58.

Yazıcı, K. (2006). Değerler Eğitimi'ne Genel Bir Bakış. Türklük Bilimi Araştırmalarl, 19, 499-522.

Yıldırım, A. ve Şimşek, H. (2006). Sosyal Bilimlerde Nitel Araştırma Yöntemleri. Ankara: Seçkin Yayınları.

Yiğittir, S., ve Kaymakçı, S. (2012). Sosyal Bilgiler Dersi Öğretim Programı Uygulama Kılavuzu'nda Yer Alan Etkinliklerin Değer Eğitimi Yaklaşımları Açısından İncelenmesi. Ahi Evran Üniversitesi Kırşehir Eğitim Fakültesi Dergisi (KEFAD), 13(2), 49-73.

Yörükoğlu, A. (2008). Çocuk Ruh Să̆lı̆̆l: Çocuğun Kişilik Gelişimi, Eğitimi ve Ruhsal Sorunları (29. Baskl). İstanbul: Özgür Yayınları. 